\title{
QUO VADIS CIVIL JUSTICE IN THE CURRENT SOCIETY?
}

Silvia Barona Vilar

(Ord. Professor of Civil and Criminal Procedure Law;

Chair of Grupo MedArb UV; Universitat de València;

President of Arbitration and Mediation Court (Valencia Chamber of Commerce)) 



\section{QUO VADIS CIVIL JUSTICE IN THE CURRENT SOCIETY?*}

Index
I. Introduction
II. Monopolization of civil process, one Face of Civil Justice in the XX Century
III. Metamorphosis of the Process: Evolution from the 20th Century to the 21st Century
1. The right to Access Justice
2. Crisis of the paradigm of Justice in the 21 st Century
IV. Challenges and Transformations of Civil Justice in the 21st Century
1. Need for an increased budget for Justice
2. Proactive Judge, Female Judges and urgent Depoliticization
3. Towards the so-called E-Justice
4. The multi-rooms Justice System

원고투고일 : 2017.10.03 심사일 : 심사1 2017.12.11 심사2 2017.12.12

$$
\text { 심사3 2017.12.11 게재확정일 : 2017.12.27 }
$$

* This research was made under project PROMETEOII 2014/081(GV) and Project DER 2016-74945 R

** Ord. Professor of Civil and Criminal Procedure Law; Chair of Grupo MedArb UV; Universitat de València; President of Arbitration and Mediation Court (Valencia Chamber of Commerce) 


\section{Introduction}

There are already several occasions in which I recently have had the opportunity to show my concern for the situation of Justice in the moments we live.1) A growing concern is that as I do not observe an evolution, a change, or some transformations in Justice as is occurring with the changing and complex social reality, but an annihilating demolition of values; those values that precisely have permitted the construction of a Justice for all and based on principles such as freedom, equality and fraternity, solidified not only institutions such as the process, by legally enshrining the guarantees, but also in the "ways" acting in a process resembling that of a guarantor process (procedural culture).

Over time the consecration of political and democratic social models have allowed to convert the process into a category of an instrument or alternative in exercising the fundamental right to Access Justice; it is an Instrument, certainly, but it is an indispensable instrument in achieving this and it became a guarantor of citizens, with the right to claim protection and to do so from parameters that responded from a formal structure to the achievements that modern constitutionalism has achieved.

We might think the world has changed. And with this change society and Justice has also undergone transformations. The panorama that we live offers us a desperate search for a model of Justice in which prevails in the reduction of costs of the public treasury. This economic vision that inspires national, supranational and international policies has inspired reforms, has led to changes, justified absences and minimized the process. This, as a conquest of civilization in the context of conflict resolution, became the nuclear axis of a model of social justice in which citizens acquired the leading role and the protective state assumed the role of guaranteeing them to facilitate real Access to Justice for all.

1) BARONA VILAR, S., "Justicia Integral y "Access to Justice”. Crisis y evolución del "paradigma", in Mediación, Arbitraje y Jurisdicción en el actual paradigma de Justicia, Madrid, (Ed. Silvia Barona), Civitas-Thomson Reuters, 2016, 31-56; "Justicia civil a debate: qué, por qué y cómo -pasado, presente y retos de futuro del proceso civil-“, in XIII Congreso panameño de Derecho Procesal, Panamá, 2016, 45-68; "Justicia integral y tutela sin proceso", in Las transformaciones del proceso civil (Dir. Juan Francisco Herrero Perezagua), Pamplona, AranzadiThomson-Reuters, 2016, 19-43; "Justicia civil en el Siglo XXI" in Gestión de conflictos jurídicos (Abogacía y Derecho) (Dir. Ariel Mantecón Ramos), La Habana, 2016, 7-33; and more recently, "Proceso civil y penal ¿líquido? en el Siglo XXI", in Justicia Civil y Penal en la Era Global (Ed. Barona Vilar), Valencia, Tirant lo Blanch, 2017, 19-65. 
The importance of knowledge and management of the process led to the consolidation of university education in the process, with the subject of Procedural Law and with a very important amount of scientific work that has allowed to maintain the study of the process, besides the jurisdiction and the action, in one of the core-subjects of legal studies.

The 21 st century has dawned, however, with a very different reality. For many reasons, it is easy to observe how in the most prestigious foreign universities the subject of "Procedural Law" disappears from the curriculum of law, and the Chairs of "Procedural or Process Law" are replaced by "Justice", "Litigation" "ADR", "Evidence" or "Sentencing". Obviously, the process has not disappeared. There it is, and it is subject to changes, successive modifications, constantly, some of them are contradictory, almost as if you wanted to find it in a "pill of happiness," as a method of transferring it to a third the competence to solve all evils. And, of course, we want a quick response, without excessive cost and favorable to anyone asks for it. The consequence of all this has led to the creation of a collapsed procedural model, without the adequate means to respond to this litigation explosion to which OLSON2) referred to at the end of the last century, generating a great dissatisfaction among citizens.

There are many coordinates that have influenced - and are currently influential- in that transformation of the process model. We are living as if we had a pathological obsession with legal reform by trying to adapt and convert a guarantor instrument into an instrument of effectiveness, which is an instrument for citizens accessing justice in a way to solve in real time the disputes of consumers, who have replaced citizens as subjects of protection.

The ideological parameters that inspire the society of the 21 st century have destroyed some of the old values of the twentieth century, especially those that erected Justice as one of the pillars of the social and democratic state. The Justice that interest us is one that works, certainly, but in terms of the analysis of what must be understood by the functioning of Justice have shed numerous components that, beyond the essential meaning of Justice as a guardianship of citizens, has been turned into mechanisms to alleviate the expansive litigiousness that society generates in some cases, and palliate it in the swiftest and least costly way possible, even at the expense of guarantees and rights.

In that context the sublime is the economy, and everything is measured under cost-benefit parameters; The process is not an instrument of justice, probably because

2) OLSON, W.K., The litigation explosión: what happened when America unleashed the lawsuit, 1991. 
justice is not more than one of the values of the legal order, the standard of modern society, and it is becoming a service for consumers and users, who look for a result, although it would not be the best result, but in any case a result.

But people are not pleased, due to complacency and we perceive it day by day how society is becoming a factory of the dissatisfied, because they are not satisfied, because they do not know and because they receive - and the worst, they accept - the prefabricated thinking. So, Society moves in what Zygmunt BAUMAN3) defined as liquid modernity, that is, in which nothing is solid. The nation-state has ceased to be a solid state, which offered citizens a protective-hug, and in which the process was perfectly incumbent, but neither is the family solid, nor work, nor the idea of a group or community, etc.; and everything with a huge lack of the idea of commitment ${ }^{4}$ ) and respect for others. We are a group of discontented, frustrated and bewildered people, germ of the exponential growth of social, individual and collective conflict. Citizen knows the right to demand protection and does so because in the twentieth century this possibility was legally designed as a right. People protest, demand, claim, and that road that permitted the raising of guarantees in effective guardianship, that was constructed to guarantee one of the fundamental pillars of the State, has collapsed, with oxidized structures and those who participate in it as directors and managers are really exhausted.

The process is not the remedy to save this liquid society; It is the instrument to protect citizens but it is not the way to save this sick society. You are being asked for what you cannot provide for, generating in many cases frustration due to the inoperability of the State.

We are observing how the successive and unreflective process reforms at present a wobbly process model, linked to several machines, full of bypasses, that not only does not fulfill the mission of being an instrument of guardianship, but also generating frustration

3) BAUMAN, Z., Liquid Modernity, 2000, explained enormously clear, using the laws of fluid mechanics, how he viewed society. He understood that modernity, which he considered unfinished - that is why he rejected the term post modernity - was inconsistent, hence he preferred to use the concept of "liquid" and in some cases "gaseous", insofar as he considered that liquid moves with ease, flow, overflow, leach, drip, splash ... without it being easy to stop them easily, unlike what happens with solids.

4) BAUMAN, Z., Liquid Modernity, 2000. This author considers in this work that currently our agreements are temporary, passengers, valid only until further notice. 
and disenchantment. And this panorama is not only in the process, but also mainly in the judicial administration, institutions and society. A society, in which, to paraphrase Bauman, there is more anxiety, more suicides, more depression, more criminality and more fear. In that context we find symptoms of liquidity permeating everything, including the process, being able to find ourselves before a process without a body or with less body, but mainly without a soul and that is really quite dangerous.

Even with the exposed scenario, which is highly worrisome, Justice continues to function and does so, despite certain critical opinions, in a manner appropriate to the parameters and coordinates that integrate it 5 ). In this good functioning in which judges have a main role, with their personal effort fight against the inclemencies of Justice in the XXI Century.

\section{II . Monopolization of civil process, one Face of Civil Justice in the XX Century}

The monopolization of the process model within the framework of Civil Justice has been a reality, especially in continental court systems, and found its raison d'être in the social, political, economic and legal history of civilization. Civil justice was identified with the Process, even though it was not the only way to achieve it; but it was understood as the best one possible. This model of conflict resolution appeared as a static approach, linked to the idea of "public service", which is technically complex with certain formalities. The Process was progressively considered to be a conquest of civilization. This procedural model has been providing a way for the pacification of society, in addition to an established public control-system.

5) In fact we can consider that the dissonances that exist and are presented between the critical opinions of the citizens and the data that can be obtained from the functioning of justice -and not only in Spain but also in other places of Europe-, obeys in many cases to the generalization of those shortcomings that sporadically appear in some complex cases and exposed to public opinion, that is, it tends to consider as characteristic of the justice system traits that are only perceived in a part of the litigiousness that reaches the courts; most likely because they are the cases of those who know by the media or by social networks, as popular speaker of Justice. BARONA VILAR, S.; PEREZ GARCÍA, F.; IRANZO NAVARRO, A., El funcionamiento de la Justicia en España. Estructuras, recursos y resultados, Fundación BBVA, 2017. 
There is no doubt that society evolves and with it the institutions that accompany it. The evolution of peoples promotes a transformation of conflict and new ways to solve it. The social changes and its acceleration in the last decades have brought a change of era. And the change of era has been accompanied by a metamorphosis in the world of conflict and in the ways to counteract it. In this metamorphosis it shows that there is a legal life of conflict resolution beyond the process, or if you want, there is civil justice beyond the civil process ${ }^{6}$.

However, incorporating life beyond the civil process does not imply a "liquidation" of civil process. It implies assuming the essential need to diagnose typologies of conflicts and working with a plurality of ways to solve them; always under public protection. In this way citizens have not only one, but the best possible way to solve their Conflicts, learning how to manage them, even avoiding or minimizing it.

Returning to the monopoly configuration of the civil process, it is interesting to delimit the notes that characterize this process model:

Firstly, it is a static model; a model based on a pyramidal formula that in legal terms has been called heterocomposition, that is, with parts that are at the base of the pyramid and with an impartial and independent third party that plays its function supra partes. The judge is the one in charge of solving the dispute "in" the course of the process. This function is exercised through a series of actions that form a technical procedure. This technical procedure is meticulously regulated and structured in phases, with deadlines, requirements, subjects, etc. It provides security as regards actions to be undertaken and fostered predictability and certainty. For centuries the judge assumed a passive role, settled in his "ivory tower", without real contact with the parties. Because of this reason the procedural doctrine spoke about the judicial "Otherness" in the process.

Secondly, the reason for this process model was political. The consolidation of civilizations demanded an idea of the state (medieval, absolutist, revolutionary, etc.) that was designed on pillars that consolidated them politically, and in the same way, the fight for social peace through ways to solve conflicts (civil) and to impose penalties (penal). That way is what was called the Process. This did not mean, however, that only this way existed. At the same time, the process coexisted with self-composed methods, even though,

6) BARONA VILAR, S., "Justicia integral y tutela sin proceso", in Las transformaciones del proceso civil (Dir. Juan Francisco Herrero Perezagua), cit., 19 ff. 
to the extent that the State "pampered" the process - because it was interested in it -, the other mechanisms (autocompositio) lost interest as methods of conflict resolution.

In this way, the political ups and downs, the hardening of political systems, the strengthening of the State, and with it public control, led to the promotion of the state process, civil procedure, with the abandonment, in practice, of institutions that continued in the Laws but with little pulse, in conciliation or arbitration. The legal design of the process and the preparation of lawyers in the management of their techniques gradually expanded the idea that conflict involved litigation, was probably much more pronounced in the continental model than in common law.

\section{Metamorphosis of the Process: Evolution from the 20th Century to the 21st Century}

Gradually, the idea of process as a simple instrument for social peace and to solve conflicts was giving way to the constitutional recognition of the process as a right, and not as a simple right, but as a fundamental right and guarantee for citizens.

\section{The right to Access Justice}

The modern Constitutions of the 20th and 21st centuries recognize the right to effective judicial protection or the right to due process or what in the Anglo-Saxon model is called the right to Access Justice. The reason for this change lies in the role played by the State in society. Structures are transformed, the meaning of the public sphere is reinforced and the judicial process and the courts of justice are strengthened. This new vision of Justice demanded greater responsibility of the State, both in the preparation of its legal operators and in the configuration of the process model and procedural rules.

The conquest of rights, the recognition of citizenship, the need to protect especially vulnerable sectors, the development of technology, the reduction of borders, the international texts of rights and freedoms, the incorporation into democratic and social systems, have been also marking the agenda in the area of Justice, creating expectations of

citizens by promoting pilot projects, that favor Justice Improvement Plans, making Justice 
one of the bastions of the social and democratic State, recognized in International Agreements and in modern constitutions of 21 th and 21st centuries. All of them were consequences of the conquests reached in the 18th and 19th centuries.

In this scenario the conception of Justice, of the Judicial Power, even when it was designed for particular rights and interests, was inexorably penetrated in the area of the "public sphere"; reason why the exigencies of public policies were made indisputable, favoring a vision of Justice as a real "right" of citizens. Beyond this legal and constitutional recognition, only the firm conviction of public policies in the promotion and, above all, the improvement and adaptation to the reality of the 21 st century demand a constant transformation and improvement of the instruments, the subjects and the structures that make possible the reality the citizens' right to Access Justice.

However, the twentieth century was accompanied by a transformation in all areas of life: technological advances, in medicine, in certain scientific areas, industrial transformation and with it the migratory movement that allowed the development of the modern city, with a much higher population density. The early decades of the 20th century in most countries, developed or not, were not easy for the majority of the population: epidemics, famine, slavery for some, wars, demographic disasters, massacres, genocides, economic crises, etc., that provoked a migratory movement, especially from Europe towards America.

But in the 20th century the social state found good accommodation in the international recognition of human rights, in the acceptance of social policies of employment, equality, Justice, among others. Precisely from this point the idea of social justice began to be constructed that was not established at that time, and this idea was incorporated in modern Constitutions. This incorporation was especially linked to the right to effective judicial protection or the right to due process. This acknowledgement implied a new persuasive process in the construction of citizens' rights. And from there began the transformation of the procedural model, becoming an instrument for citizens, as a way to achieve that idea of justice, as a recognized fundamental right. It was not a right referring only to Criminal Justice, but to general judicial protection in all areas of life and, therefore, also to Civil Justice. Thus, the process ceased to be a simple instrument for resolving conflicts, and became an instrument for the exercise of a fundamental right, the right to Access to Justice.

And so, gradually, the sense of the right to Access Justice was constructed, in a 
different manner, but at the same time was universally harmonized. Probably because beyond the "technical" instrument, it is a political instrument controlled by the State, that conforms, respects, promotes and finances it.

The State acquired a role as a "protector" of citizens, and that protective mission has necessarily led to changes in the civil process. On the one hand, new civil procedural codes were adopted in some countries; and in others, the existing ones were transformed; And, on the other hand, countries were responsible for those who controlled this process and to do the best possible changes regarding training, knowledge, loyalty, independence, impartiality, transparency and ethics in their behavior. The State is responsible for all of this, because it is all part of the State.

\section{Crisis of the paradigm of Justice in the 21st Century}

The great transformations of the 21 st Century have been provoked by Globalization. A global and globalized society emerges, in which the local and the global is merged, generating a sort of legal glocalization, which clearly has been seen in the process.

Globalization has tempered -and in some cases undoubtedly devastated- the singular, the identificative, the idiosyncrasy of peoples, homogenizing ways, cultures, tastes, and of course legal rules. Certainly the legal sphere has resisted some of the national identities and despite this uniform legal movement, has prevailed in some situations in the identity of each nation. That is why thinking globally has been reflected locally, especially in some of the reforms that have appeared in the 21 st Century, creating what has been called "legal glocalization."

It is not a minor point referring to the term "glocal". It was used by some sociologist s7), with Roland Robertson being the first to use the term, even though it is said to have its origin in Japanese commercial practices ("dochakuka"). It is sociology that has been concerned with analyzing the meaning of the term globalization and of localization. It is perhaps in the recent times in which it has come to be considered that both (globalization and localization) are in a process of a joint experiment, which is tense and contradictory. However, they are part of the same procedure, walking together and starting from a logical postulate: nothing can be created globally, but must be locally generated8).

7) The term "glocalization" firstly appeared in a late 1980s publication of the Harvard Business Review. 
And definitely it inspires and is directed to conform to the entire planet an identical economic, political, cultural, communicational and, of course, legal system. Rolanson') held that there are many occasions in which the local is the result of a globally widespread meaning. It does not prevent it in certain cases, in which also accept that there is a global discourse that comes from the local, which is usually linked to the phenomenon of the Americanization of the planet. Ulrich Beck also took the expression "glocalization" by sharing the position developed by Robertson10). So, the term "glocalization" enables to speak of "thinking globally and acting locally".

"Glocalization" is very present in the matter of Justice. We just have to observe that this legal glocalization shows, on the one hand, an enormous prevalence of efficacy and efficiency criteria above any other measurement parameter and, on the other hand, a tendency toward harmonization, if not homegenenization, of Justice in numerous legal systems, and also in procedural reforms. Interregional movements, international institutions and organizations in defense of fundamental rights and freedoms have promoted a general framework of regulations -soft law-, standard codes, which have been implemented in many parts of the world. This promotes knowledge of the rules, but, additionally, promotes a loss of certain aspects of peoples' identities.

And, added to this, gradually new legal actors have been incorporating some functions that in the 20th century were of the exclusive jurisdiction of the State are now outsourced, such as notaries, registrars, mediators, arbitrators, etc appear and have a function in Justice. They were not part of the classical structure of Justice. The old paradigm of liberal justice, established by the State as a power structure, as a political entity, and guarantor of the rights of its citizens, is giving way to a different scenario in which the same States are giving up part of their sovereignty. Now the process is not the only way and judges are not only actors in the world of Justice.

8) ABELLA VÁZQUEZ, C., “Globalización y multiculturalismo: ¿son posibles las democracias multiculturales en la era del globalismo”,

http://www.ub.edu/geocrit/sn/sn-135.htm\#_edn36.

9) ROBERTSON, Roland. Glocalization: Time-Space and Homogeneity-Heterogeneity. In FEATHERSTONE, Mike; LASH, Scott y ROBERTSON, Roland (eds.). Global Modernities, London: Sage, 1997, p. 25-44. But previously at a 1997 conference on "Globalization and Indigenous Culture", Roberston stated that "glocalization" means the simultaneity - the co-presence - of both universalizing and particularizing tendencies.

10) BECK, U., What Is Globalization?. Cambridge: Polity Press, 1999. 
There is a real paradigm shift. A crisis of the model; A crisis that appears as a faithful reflection of a change in the essential values that direct the new perspectives of Justice in postmodernity; In which - undoubtedly - the efficiency of the model is prima facie compared to the satisfactory protection of citizens. A true metamorphosis takes place, with a disturbing and paradoxically a contradictory scenario in certain cases.

Extrapolating this idea of a paradigm shift, is undoubtedly that in the modern, current, global, economic, digital, technological, and also liquid society -as Bauman11) said- in which we move, the parameters or standards of justice have changed. We live in an increasingly complex society. If the industrial revolution of the eighteenth and nineteenth centuries was developed leaving intact layers of society, the technological revolution of the 20th and 21st centuries, with its included crisis(ideological and economic), affects all layers and social spheres, altering their bases, generating new legal realities and, with them, new types of litigiousness.

A phenomenon that OLSON named "litigation explosion"12) took place at the end of the 20 th century and with special character during the 21 st century. Although this author referred to the situation in the United States of America, certainly the captured image of the litigiousness has been extended, becoming an element indissolubly linked to modern society. The litigation explosion had a lethal effect on the model of justice to which our society was traditionally linked, and in which the State is the holder of the jurisdictional power, and its courts, with those who judge and enforce what was tried. That was the paradigm of classical Justice, which has been expanding worldwide for centuries.

This litigation explosion promotes an increase in the duration and cost of litigation,

11) BAUMAN, Z., Liquid Modernity, 2000. Zygmunt Bauman advocates for the idea of "liquid modernity". Bauman's liquid modernity is a term that he used to defend that we are not in the modern era, nor in the postmodern one. We live in a liquid modernity, fragile, temporal, vulnerable and inclinated to constant change. "To "be modern' means to modernize - compulsively, obsessively; not so much just 'to be', let alone to keep its identity intact, but forever 'becoming', avoiding completion, staying underdefined. Each new structure that replaces the previous one as soon as it is declared old-fashioned and past its use-by date is only another momentary settlement - acknowledged as temporary and 'until further notice'. Being always, at any stage and at all times, 'post-something' is also an undetachable feature of modernity".

12) OLSON, W.K., The litigation explosion: what happened when America unleashed tha lawsuit?, 1991. Olson considers that there is a huge liability of lawyers in that litigation explosión. He cites Shakespeare, in his work Henry VI when he stated that all lawyers should be killed, considering that they bear a great responsability for the business that has been created around litigiousness. 
affecting citizens, in addition to increasing the workload of the courts and inoperability of the State to offer the citizen a swift, efficient and more accessible model of conflict resolution.

A new reality in the search for the protection of citizens has made its way in this complex society. To this new reality and to these new challenges we dedicate the following pages.

\section{Challenges and Transformations of Civil Justice in the 21st Century}

The paradigmatic model of justice is subjected to pressure, and is not able to fulfill the expectations generated by the parties as a system to ensure full compliance with the right to access justice. This position is reflected to one degree or another in many countries of the world, and in that unstoppable and feverish legislative activity that tries to adapt an "analogical" and static Justice to a "digital", flexible one with real time Access. Because of this reason, a worldwide proliferation of rules and regulations is accruing without control. And that is generating a sort of anomy, especially in continental legal systems.

This metamorphosis of Justice in the glocalized society implies for some people an evolution, a transformation or a change; for others, an identity crisis.

Gradually the Civil Process of the 21st Century was being designed. A process that today is built on the idea of an analogical, static and national Justice that goes deeper into an idea of a digital, dynamic, adaptable Justice without borders, which is obviously public, but incorporates new instruments of Justice, giving rise to a clear notion of integral justice13). It is a civil process that is incarnated in the "megaconcept" of civil justice and offers a very different landscape to that reached in the 20th Century. This global justice means a true paradigm shift and model of crisis; a crisis that is presented as afaithful reflection of the change of the essential values that direct the new perspectives of Justice of post modernity(or, as Bauman considered, in unfinished modernity).

13) BARONA VILAR, S., “"Justicia Integral” y Access to Justice. Crisis y evolución del "paradigma", in Mediación, Arbitraje y Jurisdicción en el actual paradigma de Justicia, cit., 2016. 
Among the reforms that have been introduced in most national legislations is a proactive judge and greater direct intervention of the parties to the conflict in the process, incorporation of communication and information technologies that are more and more turning Justice into eJustice (Electronic Justice), the search for greater procedural agility reduction of the number of procedures and their duration times - incorporation of orality and greater immediacy, concentration and publicity, and promotion of institutions that favor greater efficiency of the procedural model such as precautionary measures, interim execution, trial judgment, etc.

Moreover, there are not only changes in the model but also in the actors. It is especially significant to note that the conquest of the term "citizens" is giving way to the notion of "consumers". And in that assignment there is an absurd conversion of the model of Justice. What prevails is obtaining a good service or product at a good price and in a short space of time, and, if possible, in real time, highly favored by a world marked by the intensive development of new information and communication technologies ${ }^{14)}$. There is an economic vision of who should be protected. The law is interested in protecting the consumer, who has replaced the concept of "citizen". In this way, consumers rights, consumer protection, consumer associations, etc, and means to protect consumers in a quick, agile, flexible, and dynamic way, with special rules have appeared. The consumers' protection is a new face of Justice.

It connects perfectly with this new modality of global capitalism that inspires the idea of efficacy and efficiency as interpreting parameters of the whole model. Becker and Posner, authors of the Economic Analysis of Law, are present in the new legislation. It is about cost and benefit. Seeking Justice at the lowest cost is one of the criteria underlying the unstoppable reforms that are taking place all over the world.

HABERMAS held that leisure, consumption promoted by the new cultural industries, commercial advertising and the media transform us from public glorification into a mass consumer of mass culture, and this results in the fact that there is no individual response of criticism of the publicity received, and the sphere of the private has been invaded by the media, new technologies and also (in our opinion) social networks ${ }^{15}$ ).

14) CUBERT, J., La glocalización de la (in)seguridad, La Paz, Plural Editores, 2006, 69.

15) HABERMAS, K., Problems of the Legitimacy of Late Capitalism, 1973. He speaks of the identification of the individual with propaganda and information manipulation, or what is the same the appearance of the mass society. It also refers to the "paradigm shift" in which there has been a change, a shift in the philosophy of 
In this current paradigm of Justice it is possible to enumerate some of the challenges that this facing it.

\section{Need for an increased budget for Justice}

It is essential to have more financing to achieve the Justice model that is intended (personal media, materials, training, infrastructures, computer systems, etc.). This is not an indeterminate increase, but after the completion of a study of needs to be taken as an example of a geographical map showing population density, analysis of existing resources, typology of usual conflicts, communication facility, etc. From this data it is possible to make a budget proposal regarding the needs of the creation of courts, more personnel, spaces, etc....

Without budget allocation, the process system and in general Civil Justice is not that it is unable to function, but becomes gaseous, beyond its liquid consideration. The state budget for Justice is fundamental to be able to hold one of the essential pillars of the State. The concern of the political powers is shown not only by legislating, but also by adapting the institutions, structures, and personnel to the required needs of Justice in the 21 st century.

\section{Proactive Judge, Female Judges and urgent De- politicization}

In relation to the participation of judges in the Justice system there are several points that deserve our attention.

Firstly, the role of the judge in the new civil justice paradigm has changed. The Judge has ceased to be in his ivory tower and assumes a proactive role, much closer to the parties in conflict. They participate in the judicial procedure with increased managing and decision faculties. This new role needs to maintain his/her status of independence and

language, and in which the radical democratic inspiration of American pragmatism has been given through the concept of communication community (Influenced by Charles S. Peirce, founder of semiotics or theory of signs, and Karl-Otto Apel, a neo-Kantian philosopher who introduced American pragmatism in Germany (Communicative Action Theory, published in 1981). 
impartiality. For that, it is necessary to guarantee the Statute of judges and of the personnel in the service of Justice, and in particular the independence, impartiality and responsibility, as well as the control mechanisms of these, which favors, in any case, Access to transparency and accountability and from this, a judicial and non-judicial model that generates reliability and credibility.

Secondly, one of the challenges closely linked with the subject that occupies is precisely the depoliticization of Justice, the true separation of powers and minimal interference in the questions of the Judiciary by politicians. A task that is more than complex, if not impossible to achieve.

Lastly, in the new judicial landscape the role of women in Justice is growing exponentially. The number of female judges, female lawyers, female notaries, female solicitors, etc is highly representative. There are two aspects that deserve to be emphasized: on the one hand, it will be necessary to assess whether the integration of women in Justice will have had a new way of confronting and resolving the conflicts that arise. And, on the other hand, it will be necessary to analyze if this numerical growth of women in the Justice also considers in the mid-term an assumption of positions of responsibility and positions in the supreme courts, breaking the glass ceiling that existed. One of the challenges for Justice will therefore be the absolute integration of women jurists in positions of judicial responsibility.

\section{Towards the so-called E-Justice}

We are moving towards the so-called e-Justice or electronic Justice, removing the use of paper, to either develop, the whole civil process or only some acts, through electronic means. So, among the future challenges for Justice, and even when we can affirm that at this point the search situation of "zero paper" is just in the present.

Our Justice now includes videoconferences, digital signatures, electronic documents and electronic communications. However, it is understood that a further step towards e-Justice must be taken, by means of the full incorporation of ICTs for a more accessible, higher-quality justice system capable of guaranteeing legally recognized rights quickly and effectively, with transparent, swift and efficient processes. 
Undoubtedly ICTs are the essential tools to handle this task, taking a qualitative leap and placing the judicial system in the era of the information society16). ICTs have not only become a tool of the civil process, but also have invaded the area of ADR, which in these cases are renamed ODR (On line dispute resolution). This, however, does not entail that the electronics and industrial horizon 4.0 will save Justice from all its evils. Probably what it will allow is to reduce the "human" role that is required and needed in all facets of Justice, replaced by machines, through which it automatically seeks to obtain "protection". The issue is if Justice and dehumanization or a sort of robot-like Justice could be considered as real Justice. There is a great challenge facing us in the new millennium.

\section{The multi-rooms Justice System}

Finally, the current challenge in civil justice is to integrate ADR ${ }^{17)}$ into the justice model of the 21 st century. Today we can say without fear of being mistaken that "there is justice beyond the civil process". And a priori that is something positive.

Those media, that emerged at a given moment as mechanisms against the system, giving rise to "alternative" methods to the state-configured system, namely, the courts, have ceased to be so -alternative- and gradually have been integrated in the courts and with the Judicial process. It is, after all, now there is talk of it in the Anglo-Saxon models in Adequate (no alternative) Dispute Resolution. Thus, negotiation, mediation, conciliation, arbitration, mixed methods such as med-arb, etc., are part of a model of justice in which there is no exclusive monopoly of the Courts and in the Judicial Process. All mechanisms for resolving conflicts based on available interests are incorporated.

The challenge of the current legal systems is not to regulate negotiation, conciliation, mediation and arbitration, but also how to regulate them by integrating them into the procedural systems, making them elements of a model of integral justice, understood as a "Megaconcept" that integrates Jurisdiction and ADR.

The European Union, through its different instruments, has played a main role in this

16) GONZÁlEZ MALABIA, S., "Las TIC en el nuevo modelo de Justicia”, in Mediación, Arbitraje y Jurisdicción en el actual paradigma de Justicia, (Ed. BARONA VILAR, S.,), Pamplona, Thompson-Reuters-Aranzadi, 2016, 57-58.

17) BARONA VILAR, S., Solución extrajurisdiccional de conflictos. ADR y Derecho Procesal, Valencia, Tirant lo Blanch, 1999. 
evolution, encouraging Member States to implement national legislation on alternative dispute resolution mechanisms. ADR mechanism and Jurisdiction coexist and bring a new panorama with different vision and more possibility to repair and solve the conflicts of the citizens.

But in this moment of fascination, we should point out some concerns: on the one hand, its positive to have different methods to allow citizens to solve their disputes, specially taking into account that some of these mechanisms involve a way to face human relationships, contribute to self-responsibility and favour communication, comprehension and listening between parties. However, on the other hand, the implementation of ADR mechanisms is not neutral. What will this mean?

ADR methods contribute to a new perspective of Justice of the 21th century, a plural and global perspective, in which judicial process coexist with extrajudicial mechanisms that in some cases permit the avoidance of judicial actions and, in others, simply reduce them. So we can talk about shared Justice. This Multi-door-Justice System can be integrated in Article 6 of the European Convention of Human Rights as well as in Article 47 of the Charter of Fundamental Rights of the European Union. We presently have a global model that seems to have more advantages than disadvantages.

\section{Conclusion}

A new concept of Justice appears, the Access to Justice broadens its scope of application, is what we call "global Justice" or the so-called "Multi-rooms Justice System", a new system in which ADR mechanism and ordinary jurisdiction coexist, including both "out of Court" and "in Court" methods.

Probably this movement sought a way to find the most appropriate method of solving conflict or even achieve a settlement, taking into account the typology of the conflict. So, the objectives are: on the one hand, to create different dispute resolution methods, and on the other, to reduce the cost that results from the increasing number of disputes, a difficult problem to manage in the short or mid-term. For these reasons, we are nowadays experiencing a sort of fascination with the extrajudicial dispute resolution methods and, especially, for mediation. Everyone wants to be a mediator. 
And ADR methods contribute to a new perspective of Justice of the 21th century, a plural and global perspective, in which judicial process coexist with extrajudicial mechanisms that in some cases permit the avoidance of judicial actions and, in others, simply reduce them.

However, there is an important risk: governments can have an economically driven vision of this integration between courts and ADR mechanisms.

I mean, ADR mechanisms involve the participation of private professionals, outside the government structure, obviously this implies a lower cost for the ordinary Justice system and, therefore, for the state budget. Public expenses could be reduced. This consideration is present and can be attractive, but also quite dangerous if we are talking about Justic $\mathrm{e}^{18)}$. The governments could seek more efficiency at a lesser cost and this would result in a gap between rich and poor ${ }^{19)}$.

Being aware of the great benefits that ADR mechanisms have, such as reducing conflicts, cutting the distance between parties and promoting the building of mutual respect; being also aware of the huge advantage that global Justice implies, a system in which courts, ADR methods, mediators, arbitrators, etc., coexist, allowing for an improvement of the traditional system by increasing agility and promoting the termination of the conflict and, therefore, citizens satisfaction; it is sad to observe how, sometimes, the politicians observe Justice, courts and ADR methods as a sort of nuisance, forgetting that Justice is an essential pillar of a democratic state.

To conclude, we can talk about a new Justice paradigm by promoting a model of global Justice that includes jurisdiction and ADR, new legal actors and whose aim is, in essence, improving the protection of citizens, and is not only possible, but also highly recommended, providing that the trees (economically driven) allow us to see the wood ${ }^{20}$ ).

18) WAGNER, G.,"Harmonization of Civil Procedure- Policy Perspectives", en X.W. KRAMER and C.H. VAN RHEE, Civil Litigation in a Globalising World, Heidelberg, Springer, 2012, 93 and 112.

19) ESPLUGUES MOTA/BARONA Vilar, (Eds), "ADR Mechanisms and their Incorporation into Global Justice in the Twenty-First Century: Some Concepts and Trends”, en Global Perspectives on ADR, Cambridge, Ed Intersentia, 2014, 1-52.

20) BARONA VILAR, S., "Integración de la mediación en el moderno concepto de Access to Justice. Luces y sombras en Europa”, en InDret, octubre 2014, http://www.indret.com/pdf/1092.pdf 


\section{The list of reference}

\section{[Book]}

BARONA VILAR, S., Solución extrajurisdiccional de conflictos. ADR y Derecho Procesal, Valencia, Tirant lo Blanch, 1999.

BARONA VILAR, S., PÉREZ GARCIA, F., IRANZO NAVARRO, A., El funcionamiento de la Justicia en España. Estructuras, recursos y resultados, Fundación BBVA, 2017.

BAUMAN, Z. Liquid Modernity, 2000.

BECK, U., What Is Globalization?. Cambridge: Polity Press, 1999.

CUBERT, J., La glocalización de la (in)seguridad, La Paz, Plural Editores, 2006, 69.

HABERMAS, K., Problems of the Legitimacy of Late Capitalism, 1973

OLSON, W.K., The litigation explosion: what happened when America unleashed the lawsuit, 1991.

\section{[Book's Chapter]}

BARONA VILAR, S., “Justicia Integral y “Access to Justice”. Crisis y evolución del "paradigma", in Mediación, Arbitraje y Jurisdicción en el actual paradigma de Justicia, Madrid, (Ed. Silvia Barona), Civitas-Thomson Reuters, 2016.

BARONA VILAR, S., "Justicia civil a debate: qué, por qué y cómo -pasado, presente y retos de futuro del proceso civil-“, in XIII Congreso panameño de Derecho Procesal, Panamá, 2016.

BARONA VILAR, S., "Justicia integral y tutela sin proceso", in Las transformaciones del proceso civil (Dir. Juan Francisco Herrero Perezagua), Pamplona, Aranzadi-Thomson-Reuters, 2016.

BARONA VILAR, S., "Justicia civil en el Siglo XXI" in Gestión de conflictos jurídicos (Abogacía y Derecho) (Dir. Ariel Mantecón Ramos), La Habana, 2016.

BARONA VILAR, S., "Proceso civil y penal ¿líquido? en el Siglo XXI", in Justicia Civil y Penal en la Era Global (Ed. Barona Vilar), Valencia, Tirant lo Blanch, 2017. 
GONZÁLEZ MALABIA, S., "Las TIC en el nuevo modelo de Justicia”, in Mediación, Arbitraje y Jurisdicción en el actual paradigma de Justicia, (Ed. BARONA VILAR, S.,), Pamplona, Thompson-Reuters-Aranzadi, 2016. ROBERTSON, Roland. Glocalization: Time-Space and HomogeneityHeterogeneity. In FEATHERSTONE, Mike; LASH, Scott y ROBERTSON, Roland (eds.). Global Modernities, London: Sage, 1997, p. 25-44

\section{[Internet]}

ABELLA VÁZQUEZ, C., "Globalización y multiculturalismo: ¿son posibles las democracias multiculturales en la era del globalismo", http://www.ub.edu/geocrit/sn/sn-135.htm\#_edn36. 
<국문초록>

\section{현대사회의 민법이 나아갈 방안}

\section{실비아 바로나 빌라}

대륙법의 법원 체제에서는, 민사재판의 틀 안에서 적용 모형을 독점하는 것이 현실이 었다. 민사재판은 '공공 서비스' 라는 계획과 관련된 절차로 정의되었다. 그러나 세계화 에 따라 21세기에 접어들면서 큰 변화가 야기되었고, 세계화된 사회가 등장하면서 사법 체계는 가정화가 아닌 효율과 효율의 기준 및 통일화로 나아가는 경향으로 이동하고 있 다.

그리고, 이에 덧붙여, 점차적으로 새로운 법률 집행자들은 공증인, 등록원, 중재인 등 과 같이 사법적 기능을 하는, 현재는 외주화된 20세기의 독점적인 관할권에 대한 몇 가 지 기능을 통합한다. 그들은 고전적인 법률 체계의 일부가 아니었다. 권력 구조와 같은 국가에 의하여 설립된 자유로운 재판의 오래된 패러다임과, 정치 주체, 시민의 권리를 보장은 동일한 국가가 그들의 주권의 일부를 포기하는 다른 시나리오로 진행되고 있다. 이제 이러한 과정은 유일한 방법이 아니며 판사는 대법관의 세계에서서 유일한 법 집행 자가 아니다. 대체적분쟁해결(ADR)이 그 일부인, 민법에 대한 '거대개념' 이 등장하였 다. 이는 관할권과 대체적분쟁해결을 다방면의 사법체계로 통합한다. 대체적분쟁해결은 사법적 조치의 회피를 허용하는 사법 제도와 사법절차가 공존하는 다원적 및 세계적 관 점인 21세기 법무부의 새로운 관점에 기여한다. 그러나 여기에는 정부가 이러한 법원과 대체적분쟁해결 매커니즘간의 통합에 대해 경제적 기반의 비전을 가지 수 있다는 중요 한 위험요소가 있고, 또한 공공 경비가 줄어들 우려가 있다. 이러한 배려는 나쁘다고 할 수는 없지만, 사법에 대해 논하는 것이 위험해질 소지가 있다. 정부는 더 적은 비용 으로 더 많은 효율성을 추구할 수 있고, 이는 빈부격차를 초래할 우려가 있다.

주제어 : 민사재판, 법원에 대한 접근성, 대체적분쟁해결, 다방면의 사법체계, 국제화 


\section{QUO VADIS CIVIL JUSTICE IN THE CURRENT SOCIETY?}

\section{Silvia Barona Vilar}

In continental court System the monopolization of the process model within the framework of Civil Justice has been a reality. Civil justice was identified with the Process, linked to the idea of "public service". But the great transformations of the 21 st Century have been provoked by Globalization. A global and globalized society emerges, in which Justice systems are moving with efficacy and efficien cycriteria and with a tendency toward harmonization, if not homegenenization.

And, added to this, gradually new legal actors have been incorporating some functions that in the 20th century were of the exclusive jurisdiction of the State are now outsourced, such as notaries, registrars, mediators, arbitrators, etc appear and have a function in Justice. They were not part of the classical structure of Justice. The old paradigm of liberal justice, established by the State as a power structure, as a political entity, and guarantor of the rights of its citizens, is giving way to a different scenario in which the same States are giving up part of their sovereignty. Now the process is not the only way and judges are not only actors in the world of Justice. It is emerged a "megaconcept" of civil justice, in which ADR is a part of it. So, it integrates Jurisdiction and ADR, as a sort of Multi-door-Justice System. ADR methods contribute to a new perspective of Justice of the 21th century, a plural and global perspective, in which judicial process coexist with extrajudicial mechanisms that in some cases permit the avoidance of judicial actions and, in others, simply reduce them. However, there is an important risk: governments can have an economically driven vision of this integration between courts and ADR mechanisms. Public expenses could be reduced. This consideration is not bad, but could be dangerous if we are talki ng about Justice. The governments could seek more efficiency at a lesser cost and this would result in a gap between rich and poor.

Keywords : Civil Justice, Access to Justice, ADR, Multi-rooms Justice System, Glocalization 